\title{
Visualizing the Tumor Microenvironment by Color-coded Imaging in Orthotopic Mouse Models of Cancer
}

\author{
ATSUSHI SUETSUGU ${ }^{1,2,3}$, MASAHITO SHIMIZU ${ }^{1}$, SHIGETOYO SAJI ${ }^{1}$, \\ HISATAKA MORIWAKI ${ }^{1}$ and ROBERT M. HOFFMAN ${ }^{2,3}$ \\ ${ }^{1}$ Gifu University, Graduate School of Medicine, Gifu, Japan; \\ ${ }^{2}$ AntiCancer, Inc., San Diego, CA, U.S.A.; \\ ${ }^{3}$ Department of Surgery, University of California, San Diego, CA, U.S.A.
}

\begin{abstract}
The tumor microenvironment (TME) contains stromal cells in a complex interaction with cancer cells. This relationship has become better understood with the use of fluorescent proteins for in vivo imaging, originally developed by our laboratories. Spectrally-distinct fluorescent proteins can used for color-coded imaging of the complex interaction of the tumor microenvironment in the living state using cancer cells expressing a fluorescent protein of one color and host mice expressing another-color fluorescent protein. Cancer cells engineered in vitro to express a fluorescent protein were orthotopically implanted into transgenic mice expressing a fluorescent protein of a different color. Confocal microscopy was then used for color-coded imaging of the TME. Colorcoded imaging of the TME has enabled us to discover that stromal cells are necessary for metastasis. Patient-derived orthotopic xenograft (PDOX) tumors were labeled by first passaging them orthotopically through transgenic nude mice expressing either green, red, or cyan fluorescent protein in order to label the stromal cells of the tumor. The colored stromal cells become stably associated with the PDOX tumors through multiple passages in transgenic colored mice or non-
\end{abstract}

This article is freely accessible online.

Correspondence to: Atsushi Suetsugu, MD, Ph.D., Assistant Professor, Department of Gastroenterology, Gifu University Graduate School of Medicine, 1-1 Yanagido, Gifu, 501-1194 Japan. Tel: +81 582306311, Fax: +81582306310, e-mail: asue@gifuu.ac.jp or Robert M. Hoffman, PhD, AntiCancer, Inc., 7917 Ostrow Street, San Diego, CA 92111, U.S.A. Tel: +1 8586542555, Fax: +1 8582684175,e-mail: all@anticancer.com

Key Words: Tumor microenvironment, red fluorescent protein, green fluorescent protein, blue fluorescent protein, niche, cancerassociated fibroblasts, tumor-associated macrophages, collagen, liver metastasis, color-coded imaging, review. colored mice. The fluorescent protein-expressing stromal cells included cancer-associated fibroblasts and tumor-associated macrophages. The cancer cells in PDOX models can also be labeled with a telomerase-dependent adenovirus containing the gene for green fluorescent protein. Using this model, specific cancer-cell or stromal-cell targeting by potential therapeutics can be visualized. Color-coded imaging enabled the visualization of apparent fusion of cancer and stromal cells. Color-coded imaging is a powerful tool visualizing the interaction of cancer and stromal cells during cancer progression and treatment.

In vivo imaging with fluorescent proteins was pioneered by our laboratories and has been particularly useful for studying tumor growth, invasion, cancer-cell trafficking, metastasis, angiogenesis, and other aspects of tumor progression (1-5). Multicolored proteins have allowed the color-coding of cancer cells growing in vivo such as between highly- and poorly-metastatic cells, cancer stem and non-stem cells, and gene transfer between cancer cells $(3,4,6-13)$.

The present review focuses on color-coded imaging of cancer and stromal cells in the tumor microenvironment (TME).

Transgenic nude mice expressing fluorescent proteins for colorcode imaging of the TME. The green fluorescent protein (GFP)-expressing athymic nude mouse was obtained by crossing nontransgenic nude mice with the transgenic C57/B6 GFP mouse in which the $\beta$-actin promoter drives GFP. In the adult GFP nude mice, most organs brightly expressed GFP, including the heart, lungs, spleen, pancreas, esophagus, stomach, duodenum, and the entire digestive system from the tongue to the anus; the male and female reproductive systems; brain and spinal cord; and the circulatory system, including the heart and major arteries and veins. The bared skeleton also highly expressed GFP (14). 
The red fluorescent protein (RFP)-expressing nude mouse was obtained by crossing non-transgenic nude mice with the transgenic C57/B6 mouse in which the $\beta$-actin promoter drives DsRed2 including the heart, lungs, spleen, pancreas, esophagus, stomach, duodenum, bone marrow, spleen cells, the male and female reproductive systems; brain and spinal cord; and the circulatory system, including the heart, and major arteries and veins, and skeleton, all highly expressed RFP (15).

The cyan fluorescent protein (CFP)-expressing nude mouse was developed by crossing non-transgenic nude mice with the transgenic CK/ECFP mouse in which the $\beta$-actin promoter drives expression of CFP. In the CFP nude mice, the pancreas and reproductive organs had the strongest fluorescence (16).

Imaging the TME. With the use of multiple-colored fluorescent proteins, we developed imaging of the TME by color-coding cancer and stromal cells $(3,7,15,17-19)$. Color-coded fluorescence imaging of the TME is achieved, for example, by using RFP-expressing cancer cells growing in GFP-expressing transgenic mice. The host vasculature, expressing GFP, can be readily distinguished as interacting with the RFP-expressing cancer cells. GFP-expressing dendritic cells were shown to be contacting RFP-expressing cancer cells with their dendrites. GFP-expressing macrophages engulfed RFP-expressing cancer cells and GFP-expressing lymphocytes were visibly attaching to an RFP-expressing tumor, which eventually regressed (7).

Imaging the critical role of stromal cells in metastasis. With the use of color-coded imaging of the TME, we have demonstrated the essential role of tumor-associated host cells in tumor progression and metastasis $(20,21)$. Color-coded imaging of the TME has enabled important discoveries of its cellular components $(22,23)$. Using color-coded imaging of the TME, Egeblad et al. observed that regulatory Tlymphocytes migrated to blood vessels. These authors observed that stromal cells had higher motility in the TME at the tumor periphery than within the tumor mass (22).

GFP-expressing spleen cells were found in the liver metastases that resulted from intra-splenic injection of colon cancer cells expressing RFP in the cytoplasm and GFP in the nucleus, in transgenic nude mice ubiquitously expressing GFP. When cancer cells were injected into the portal vein, no liver metastasis resulted. When GFP-expressing spleen cells and the RFP-GFP cancer cells were co-injected in the portal vein, liver metastasis resulted that contained GFP-expressing spleen cells. These results demonstrate the stromal (spleen) cells were indeed necessary for metastasis (20).

Confocal microscopy imaging demonstrated the close interaction of XPA-I-GFP-RFP pancreatic cancer cells and RFP-expressing pancreatic stellate cells in a liver metastasis, in an orthotopic model, suggesting the stellate cells were necessary for metastasis (Figure 1) (24).

Patient-derived orthotopic xenograft (PDOX) mouse models of cancer. Orthotopic implantation of intact tumor tissue leads to metastasis that mimics that seen in patients. PDOX models were pioneered by our laboratories in the early 1990s and recapitulate tumor behavior, including metastasis, in the patient in contrast to subcutaneous patient-derived xenograft models, which behave as benign tumors $(25,26)$.

PDOX models, which were implanted using intact tumor tissue with the technique of surgical orthotopic implantation (SOI) $(25,27)$, were established from patients with colonic (28-30), pancreatic $(21,31-41)$, breast (42), ovarian (43), lung (44), and stomach cancer (45), and mesothelioma (46) in the early 1990s, resulting in primary and metastatic tumor growth very similar to that in the patient.

Recently, PDOX models of sarcoma (47-64), cervical cancer (65-67) as well as melanoma (68-74) have also been developed.

PDOX tumors acquired fluorescent protein-expressing stroma while growing in nude mice. A pancreatic cancer PDOX acquired RFP, GFP, and CFP stroma while growing in transgenic nude mice expressing the corresponding fluorescent protein, as described above (Figure 2). The RFP-, GFP-, and CFP-expressing stromal cells acquired by the tumors included cancer-associated fibroblasts (CAFs), tumor-associated macrophages (TAMs), and blood vessels (Figure 3). The fluorescent protein-expressing tumor-acquired stromal cells persisted throughout at least three passages in other mice (21). These studies demonstrated the persistence of the mouse TME in patient tumors through multiple passages (21).

PDOX metastasis contains stromal cells from the primary tumor. A pancreatic cancer PDOX with GFP-expressing stroma metastasized to the lung, whereby the metastases maintained the GFP-expressing stroma from the primary tumor and apparently acquired stromal cells from the metastatic sites as well, resulting in very bright fluorescence of the metastasis (Figure 4) (16).

Noninvasive imaging of a pancreatic cancer imageable PDOX labeled with GFP and RFP stroma. After passage to RFP and GFP mice, a pancreatic cancer imageable PDOX was passaged to non-transgenic non-colored nude mice, enabling noninvasive imaging at days 21, 30, and 74 (Figure 5). The noninvasive imaging demonstrated extensive orthotopic growth of the pancreatic cancer PDOX (Figure 5) (34).

We subsequently showed that an undifferentiated pleomorphic sarcoma stably acquired imageable RFP-labeled stroma after only a single passage in a transgenic RFP nude mouse that was non-invasively imageable in non-colored mice (52). 

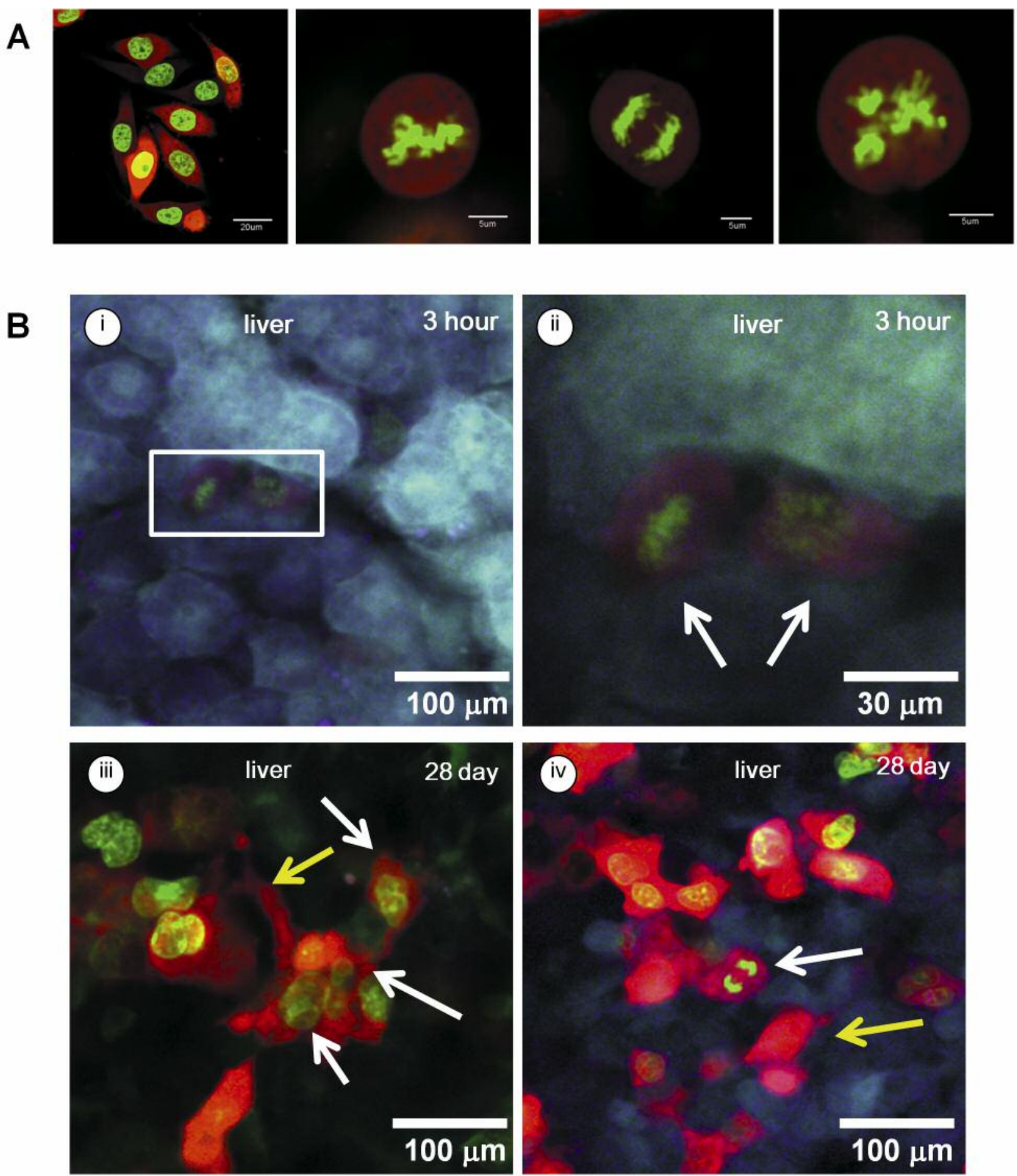

Figure 1. A: Green fluorescent protein-red fluorescent protein (GFP-RFP)-expressing dual-color XPA-I human pancreatic cancer cancer cells in vitro. Cancer cells were initially transduced with RFP and the neomycin-resistance gene. The cells were subsequently transduced with histone H2BGFP and the hygromycin-resistance gene. Double transformants were selected with G418 and hygromycin, and stable clones were established. Images were captured under FV1000 confocal microscopy (28). B: High-magnification imaging of XPA-I pancreatic cancer cells and stellate cells in the liver of cyan fluorescent protein (CFP)-expressing nude mice. A, B: XPA-I-GFP-RFP pancreatic cancer cells in the host liver 3 hours after splenic injection. White arrows indicate XPA-1 pancreatic cancer cells. C, D: Twenty-eight days after co-injection of XPA-I-GFP-RFP pancreatic cancer cells and RFP stellate cells, liver metastases were observed in the host CFP nude mice. White arrows indicate XPA-I-GFP-RFP pancreatic cancer cells. Yellow arrows indicate RFP stellate cells. White arrow in D shows dividing cancer cells. Imaging was performed with a FV1000 confocal microscope (Olympus) (24). 
A

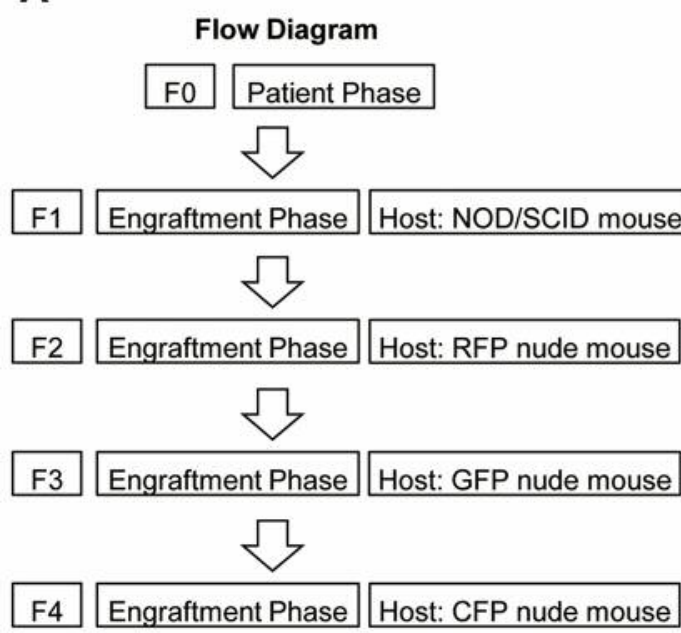

B

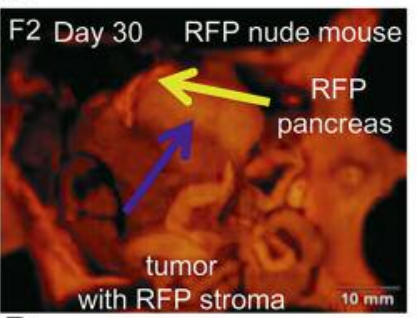

D

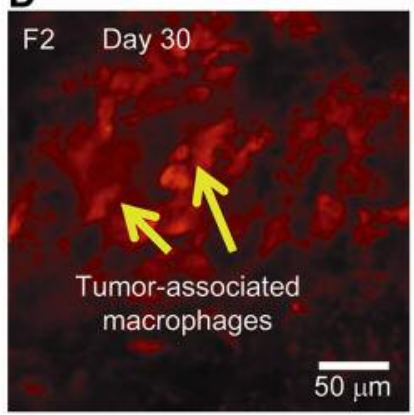

C

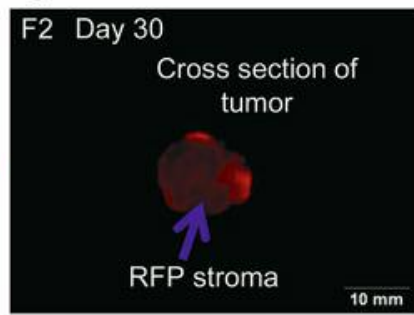

G

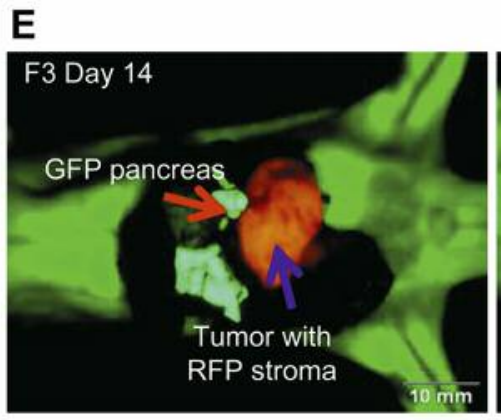

F

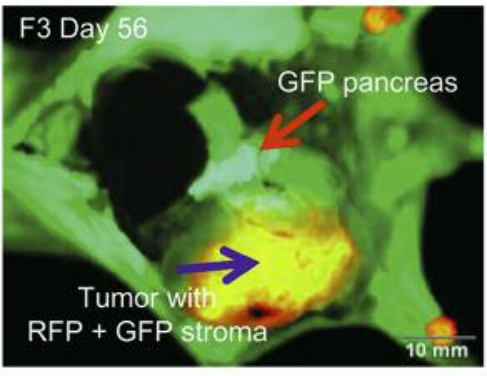

F3 Day 56

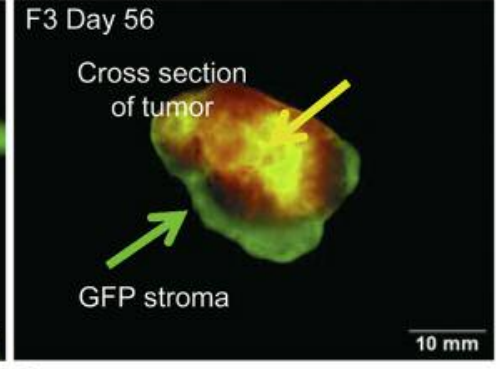

H

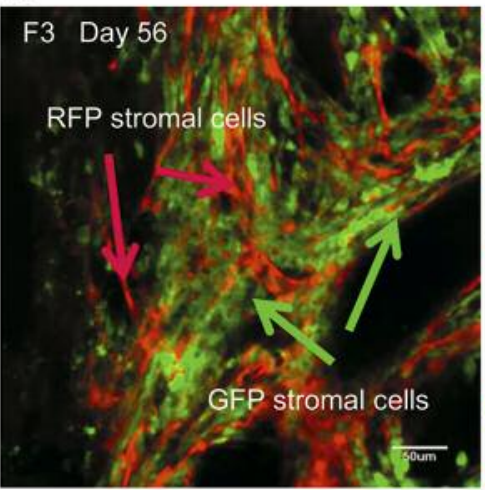

I

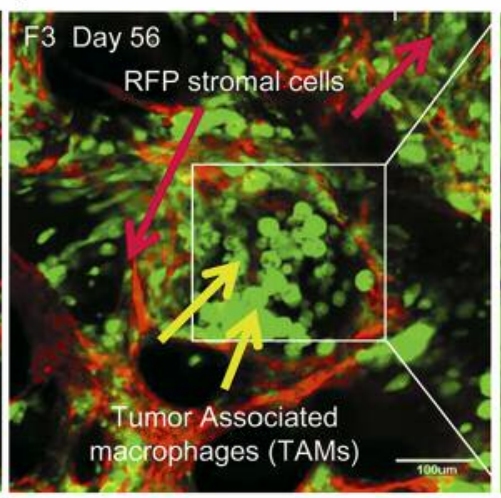

J

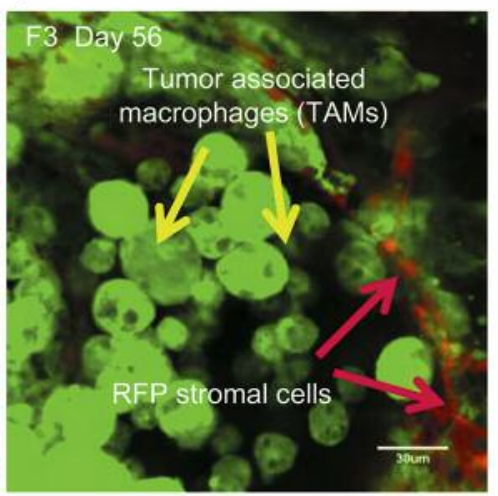

Figure 2. A: Flow diagram of the experimental protocol for imaging the tumor microenvironment. B: Pancreatic cancer patient-derived orthotopic xenograft (PDOX) transplanted to a red fluorescent protein (RFP) transgenic nude mouse. Yellow arrow indicates host RFP nude-mouse pancreas. Blue arrow indicates tumor with infiltrating RFP stroma $(B a r=10 \mathrm{~mm})$. Image obtained with Olympus OV100. C: Human pancreatic PDOX excised from RFP nude mouse with RFP stroma. The image is of a cross-section of the tumor. Blue arrow indicates RFP stroma (Bar=10 mm). D: Visualization of RFP tumorassociated macrophages (TAMs) in the human pancreatic cancer patient tumor (F2). High-magnification image. Yellow arrows indicate RFP TAMs (Bar=50 um). E: Pancreatic cancer PDOX growing in transgenic GFP nude mouse for 30 days. Red arrow indicates host GFP nude mouse pancreas. Blue arrow indicates human pancreatic tumor with RFP stroma $(B a r=10 \mathrm{~mm})$. F: Pancreatic cancer PDOX growing in GFP-host model for 56 days. Red arrow indicates host GFP nude mouse pancreas. Blue arrow indicates human pancreatic tumor with RFP and GFP stroma (Bar=10 mm). G: Excised PDOX tumor with RFP and GFP stroma. The image is of a cross-section of the tumor. Yellow arrow indicates RFP stroma. Green arrow indicates GFP stroma $(B a r=10 \mathrm{~mm}) . \mathrm{H}:$ PDOX with RFP and GFP stromal cells. Green arrows indicate GFP stromal cells from GFP mouse. Red arrows indicate RFP stromal

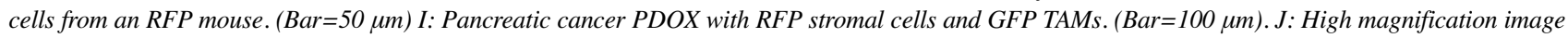
of PDOX shown in (I). RFP stromal cells and GFP-TAMs are readily observed (Bar=30 $\mu \mathrm{m})$. All images obtained with Olympus FV1000 system (21). 

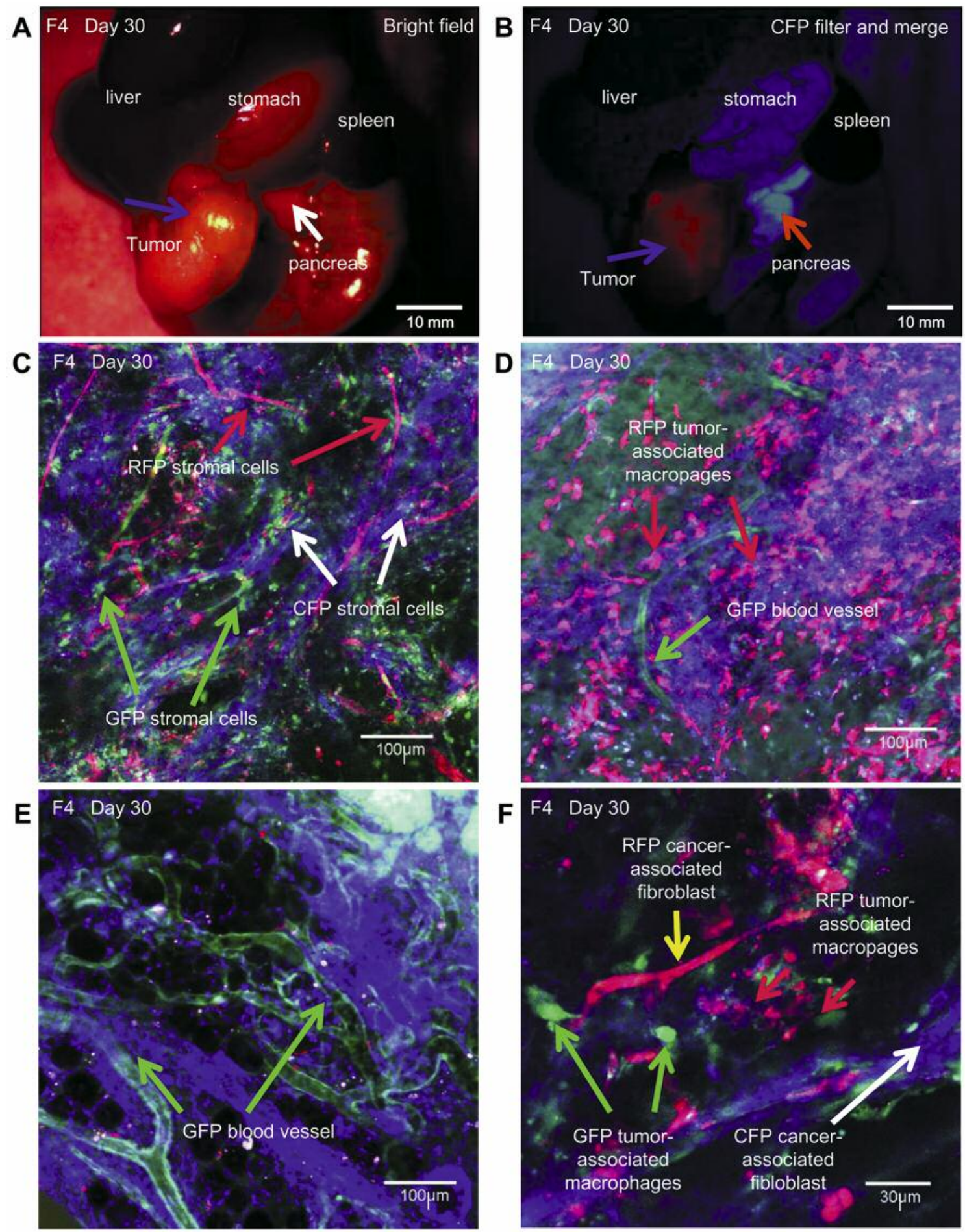

Figure 3. A: Pancreatic cancer patient-derived orthotopic xenograft (PDOX) growing in a cyan fluorescent protein (CFP)-expressing host. White arrow indicates host CFP nude-mouse pancreas. Blue arrow indicates tumor $(B a r=10 \mathrm{~mm})$. B: Pancreatic cancer PDOX (blue arrow) with red fluorescent protein (RFP), green fluorescent protein $(G F P)$-expressing, and CFP-expressing stromal cells. Red arrow indicates CFP pancreas (Bar=10 mm). C: RFP, $G F P$, and CFP stromal cells were observed. Red arrow indicates RFP stromal cells. Green arrows indicate GFP stromal cells. White arrows indicate CFP stromal cells (Bar=100 $\mu \mathrm{m})$. D: RFP tumor-associated macrophages (TAMs) (red arrow) and GFP blood vessel (green arrow) were observed in the tumor $(B a r=100 \mu \mathrm{m})$. E: GFP blood vessels (green arrows) can be seen in the tumor. (Bar=100 $\mu \mathrm{m})$. F: RFP cancer-associated fibroblasts (CAFs) (yellow arrow) and GFP TAMs (green arrows) present in the tumor. White arrow indicates CFP CAFs. (Bar=30 $\mu m)$. Images A and B were obtained with an Olympus MVX10 microscope, C-F were obtained with an Olympus FV1000 confocal microscope (21). 
A
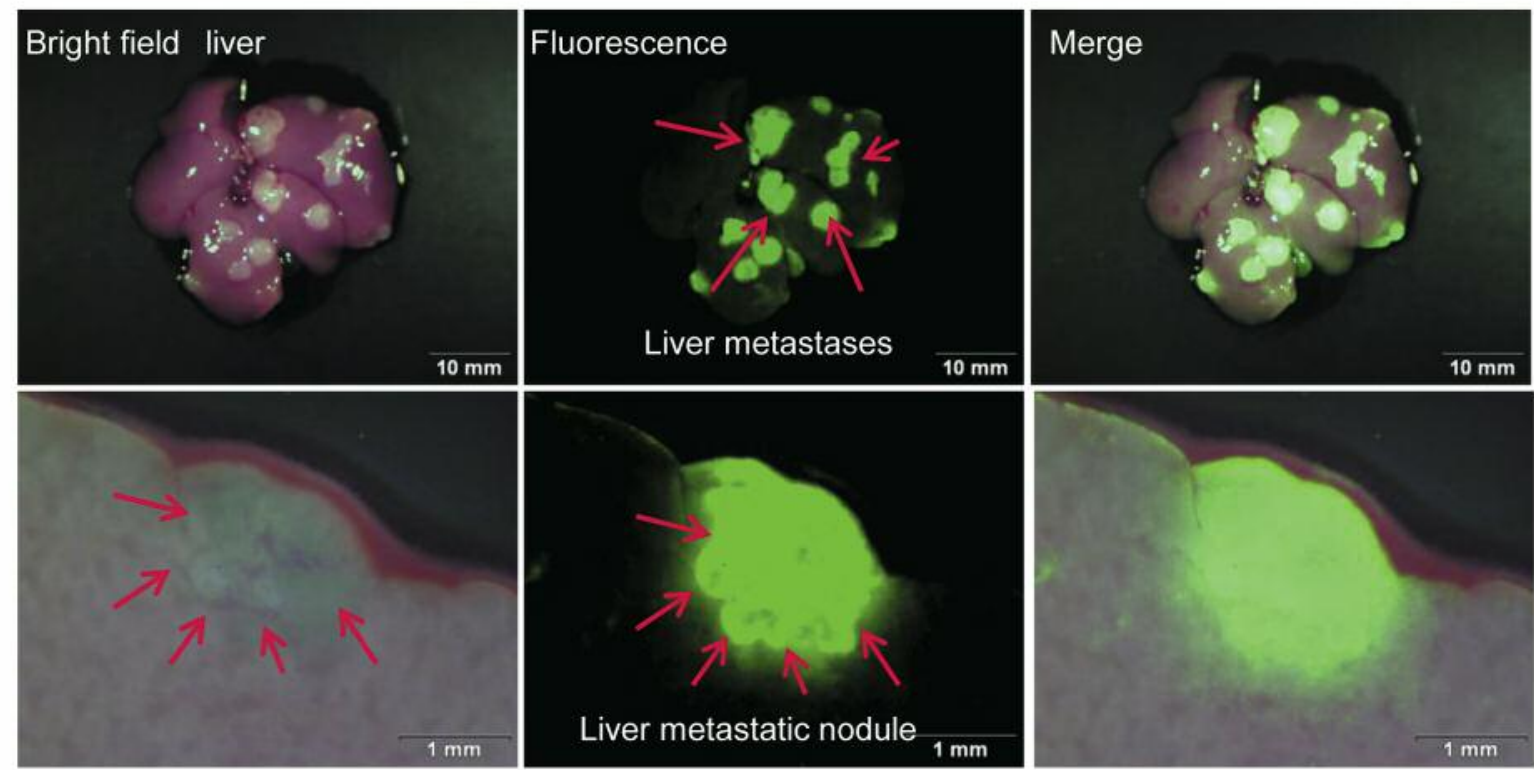

B

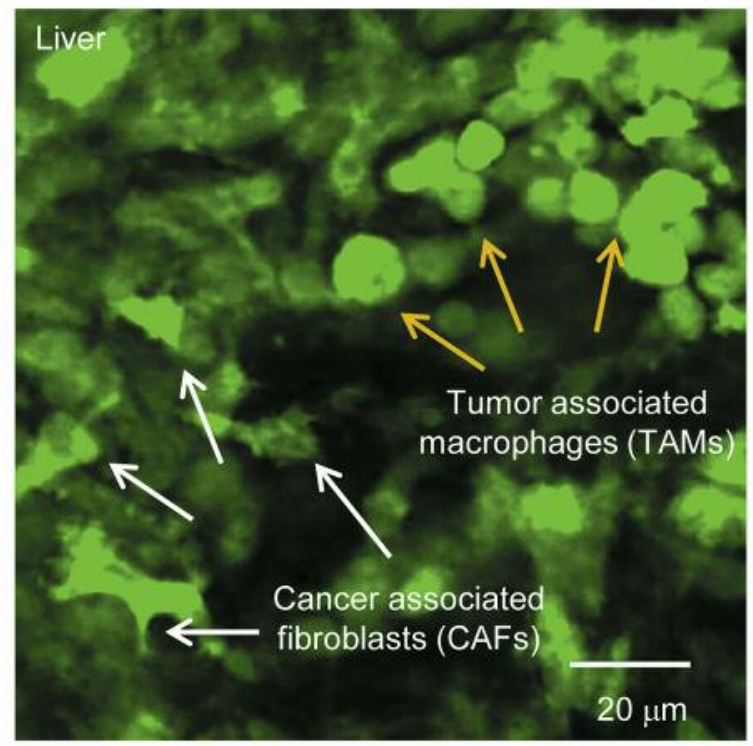

\section{C}

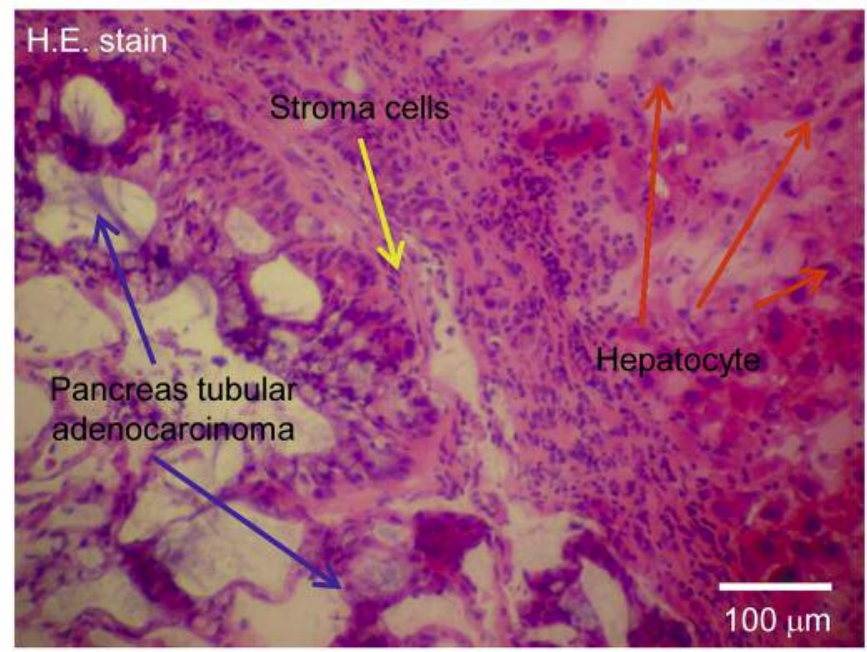

Figure 4. A: Upper image shows pancreatic cancer patient-derived orthotopic xenograft (PDOX) liver metastasis. Red arrows indicate liver metastasis with green fluorescent protein (GFP)-expressing stroma. Bar=10 mm. Lower panel shows high-magnification image of liver metastasis. Bar $=1 \mathrm{~mm}$. Red arrows indicate GFP stromal cells. B: Image of liver metastasis. Yellow arrows indicate tumor-associated macrophages (TAMs). White arrows indicate cancer-associated fibroblasts Image was obtained with an Olympus FV1000 confocal microscope (Bar=20 $\mu m)$. C: Liver metastasis stained with hematoxylin and eosin. Blue arrows indicate pancreatic tubular adenocarcinoma. Yellow arrows indicate stromal cells. Red arrows indicate hepatocytes (Bar $=100 \mu \mathrm{m})(33)$.

Color-coded imaging of TME enables effective fluorescenceguided surgery in a pancreatic cancer PDOX model. The telomerase-dependent GFP-containing adenovirus OBP-401 was used to label the cancer cells of a pancreatic cancer PDOX previously grown in an RFP transgenic mouse, where it acquired bright red stroma. Color-coded fluorescenceguided surgery (FGS) allowed complete resection of the pancreatic tumors, including stroma, preventing local recurrence, which bright-light surgery and single-color fluorescence-guided surgery were unable to do (41).

Color-coded imaging demonstrates recombination between cancer and stromal cells. Subcutaneous EL4 mouse lymphoma tumors were harvested and transplanted to the abdominal cavity 

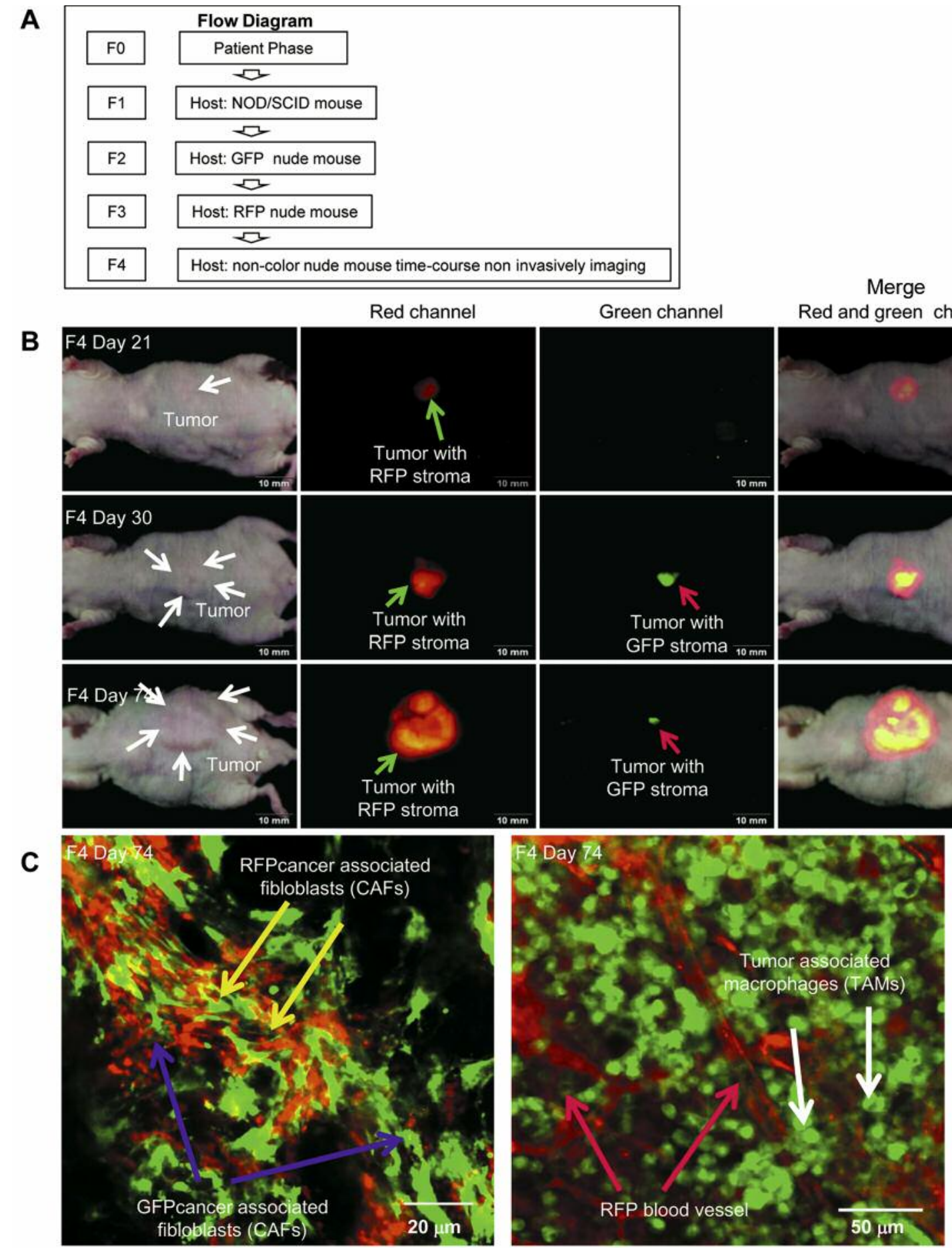

Figure 5. Non-invasive imaging of a fluorescent tumor originally from a patient with pancreatic cancer growing orthotopically in nude mice. A: Flow diagram of the experimental protocol. B: Whole-body non-invasive imaging of a pancreatic cancer patient-derived orthotopic xenograft (PDOX) in non-transgenic nude mice. Mice were non-invasively imaged at day 21 (upper row), day 30 (middle row) and day 74 (lower row). PDOX tumors were initially grown in green fluorescent protein $(G F P)$ and red fluorescent protein (RFP) -transgenic mice. Green arrows indicate tumor with RFP stromal cells. Red arrows indicate tumor with GFP stromal cells. Images were obtained with the Olympus OV100 Small Animal Imaging System. C: Resected PDOX with RFP and GFP stroma. Images were obtained with an FV1000 confocal microscope. Left panel, RFP-expressing and GFP-expressing cancer-associated fibroblasts (CAFs). Right panel, RFP-expressing blood vessels and GFP-expressing tumor-associated macrophages (TAMS). Yellow arrows indicate RFP-expressing CAFs. Blue arrows indicate GFP-expressing CAFs. White arrows indicate GFPexpressing TAMs. Red arrows indicate RFP-expressing blood vessels (34). 
of GFP-expressing nude mice. Metastases to the liver, perigastric lymph node, ascites, bone marrow, and primary tumor were imaged. In addition to EL4-RFP cells and GFP-host cells, genetically-recombinant yellow fluorescent cells were observed only in the ascites and bone marrow. These results indicate genetic exchange between the stromal and cancer cells (75).

Color-coded imaging to visualize therapeutic targeting of stromal cells. An inhibitor of transforming growth factor- $\beta$ (TGF- $\beta$ ) was shown to target stroma in an orthotopic mouse model of pancreatic cancer with a color-coded TME. The BxPC-3 human pancreatic adenocarcinoma cell line expressing GFP was used in an orthotopic model in transgenic nude mice ubiquitously expressing RFP. The area of RFP fluorescence from the stromal cells relative to the area of GFP fluorescence of the cancer cells was significantly reduced by a TGF- $\beta$ inhibitor indicating targeting of the stroma by the inhibitor. Color-coded imaging in an orthotopic pancreatic-cancer cell-line mouse model thus readily enabled detection of the selective targeting of stromal cells by a TGF- $\beta$ inhibitor (76).

\section{Conclusion}

High-resolution color-coded fluorescence imaging is a powerful technique for differentially labeling cancer and stromal cells in the tumor microenvironment (TME), allowing observations of the behavior of each cell type and their interaction within tumors, thereby better defining the specific role of cancer and stromal cells in tumor progression (77).

\section{References}

1 Chishima T, Miyagi Y, Wang X, Yamaoka H, Shimada H, Moossa AR and Hoffman RM: Cancer invasion and micrometastasis visualized in live tissue by green fluorescent protein expression. Cancer Res 57: 2042-2047, 1997.

2 Hoffman RM and Yang M: Subcellular imaging in the live mouse. Nat Protoc 1: 775-782, 2006.

3 Hoffman RM and Yang M: Color-coded fluorescence imaging of tumor host interactions. Nat Protoc 1: 928-935, 2006.

4 Hoffman RM: The multiple uses of fluorescent proteins to visualize cancer in vivo. Nat Rev Cancer 5: 796-806, 2005.

5 Hoffman RM (ed.): In Vivo Cellular Imaging Using Fluorescent Proteins: Methods and Protocols. Methods in Molecular Biology, Vol. 872, Walker, John M., series ed. Humana Press (Springer Science+Business Media New York), New York, NY, 2012.

6 Yamamoto N, Yang M, Jiang P, Xu M, Tsuchiya H, Tomita K, Moossa AR and Hoffman RM: Determination of clonality of metastasis by cell-specific color-coded fluorescent-protein imaging. Cancer Res 63: 7785-7790, 2003.

7 Yang M, Li L, Jiang P, Moossa AR, Penman S and Hoffman RM: Dual-color fluorescence imaging distinguishes tumor cells from induced host angiogenic vessels and stromal cells. Proc Natl Acad Sci USA 100: 14259-14262, 2003.
8 Yamauchi K, Tome Y, Yamamoto N, Hayashi K, Kimura H, Tsuchiya H, Tomita K, Bouvet M, Hoffman RM: Color-coded real-time subcellular fluorescence imaging of the interaction between cancer and host cells in live mice. Anticancer Res 32: 39-43, 2012.

9 Amoh Y, Hamada Y, Katsuoka K and Hoffman RM: In vivo imaging of nuclear-cytoplasmic deformation and partition during cancer cell death due to immune rejection. J Cell Biochem 113: 465-472, 2012.

10 Glinskii AB, Smith BA, Jiang P, Li X-M, Yang M, Hoffman RM and Glinsky GV: Viable circulating metastatic cells produced in orthotopic but not ectopic prostate cancer models. Cancer Res 63: 4239-4243, 2003.

11 Tome Y, Tsuchiya H, Hayashi K, Yamauchi K, Sugimoto N, Kanaya F, Tomita K, Hoffman RM: In vivo gene transfer between interacting human osteosarcoma cell lines is associated with acquisition of enhanced metastatic potential. J Cell Biochem 108: 362-367, 2009.

12 Suetsugu A, Osawa Y, Nagaki M, Moriwaki H, Saji S, Bouvet $M$ and Hoffman RM: Simultaneous color-coded imaging to distinguish cancer "stem-like" and non-stem cells in the same tumor. J Cell Biochem 111: 1035-1041, 2010.

13 Hassanein MK, Suetsugu A, Saji S, Moriwaki H, Bouvet M, Moossa AR and Hoffman RM: Stem-like and non-stem human pancreatic cancer cells distinguished by morphology and metastatic behavior. J Cell Biochem 112: 3549-3554, 2011.

14 Yang M, Reynoso J, Jiang P, Li L, Moossa AR and Hoffman RM: Transgenic nude mouse with ubiquitous green fluorescent protein expression as a host for human tumors. Cancer Res 64 : 8651-8656, 2004.

15 Yang M, Reynoso J, Bouvet M and Hoffman RM: A transgenic red fluorescent protein-expressing nude mouse for color-coded imaging of the tumor microenvironment. J Cell Biochem 106: 279-284, 2009.

16 Tran Cao HS, Reynoso J, Yang M, Kimura H, Kaushal S, Snyder CS, Hoffman RM and Bouvet M: Development of the transgenic cyan fluorescent protein (CFP)-expressing nude mouse for “Technicolor" cancer imaging. J Cell Biochem 107: 328-334, 2009.

17 Suetsugu A, Osawa Y, Nagaki M, Saji S, Moriwaki H, Bouvet $M$ and Hoffman RM: Imaging the recruitment of cancerassociated fibroblasts by liver metastatic colon cancer. J Cell Biochem 112: 949-953, 2011.

18 Suetsugu A, Hassanein MK, Reynoso J, Osawa Y, Nagaki M, Moriwaki H, Saji S, Bouvet M, Hoffman RM: The cyan fluorescent protein nude mouse as a host for multicolor-coded imaging models of primary and metastatic tumor microenvironments. Anticancer Res 32: 31-38, 2012.

19 Yang M, Jiang P and Hoffman RM: Whole-body subcellular multicolor imaging of tumor-host interaction and drug response in real time. Cancer Res 67: 5195-5200, 2007.

20 Bouvet M, Tsuji K, Yang M, Jiang P, Moossa AR and Hoffman $\mathrm{RM}$ : In vivo color-coded imaging of the interaction of colon cancer cells and splenocytes in the formation of liver metastases. Cancer Res 66: 11293-11297, 2006.

21 Suetsugu A, Katz M, Fleming J, Truty M, Thomas R, Moriwaki H, Bouvet M, Saji S and Hoffman RM: Multi-color palette of fluorescent proteins for imaging the tumor microenvironment of orthotopic tumorgraft mouse models of clinical pancreatic cancer specimens. J Cell Biochem 113: 2290-2295, 2012. 
22 Egeblad M, Ewald AJ, Askautrud HA, Truitt ML, Welm BE, Bainbridge E, Peeters G, Krummel MF and Werb Z: Visualizing stromal cell dynamics in different tumor microenvironments by spinning disk confocal microscopy. Dis Model Mech 1: 155-167, 2008.

23 Egeblad M, Nakasone ES and Werb Z: Tumors as organs: complex tissues that interface with the entire organism. Dev Cell 18: 884-901, 2010.

24 Suetsugu A, Snyder CS, Moriwaki H, Saji S, Bouvet M and Hoffman RM: Imaging the interaction of pancreatic cancer and stellate cells in the tumor microenvironment during metastasis. Anticancer Res 35: 2545-2551, 2015.

25 Hoffman RM: Patient-derived orthotopic xenografts: better mimic of metastasis than subcutaneous xenografts. Nat Rev Cancer 15: 451-452, 2015

26 Byrne AT, Alférez DG, Amant F, Annibali D, Arribas J, Annibali D, Arribas J, Biankin AV, Bruna A, Budinská E, Caldas C, Chang DK, Clarke RB, Clevers H, Coukos G, Dangles-Marie V, Eckhardt SG, Gonzalez-Suarez E, Hermans E, Hidalgo M, Jarzabek MA, de Jong S, Jonkers J, Kemper K, Lanfrancone L, Mælandsmo GM, Marangoni E, Marine JC, Medico E, Norum JH, Palmer HG, Peeper DS, Pelicci PG, Piris-Gimenez A, Roman-Roman S, Rueda OM, Seoane J, Serra V, Soucek L, Vanhecke D, Villanueva A, Vinolo E, Bertotti A and Trusolino $\mathrm{L}$ : Interrogating open issues in cancer precision medicine with patient-derived xenografts. Nat Rev Cancer 17: 254-268, 2017.

27 Hoffman RM: Orthotopic metastatic mouse models for anticancer drug discovery and evaluation: a bridge to the clinic. Invest New Drugs 17: 343-359, 1999.

28 Fu X, Besterman JM, Monosov A and Hoffman RM: Models of human metastatic colon cancer in nude mice orthotopically constructed by using histologically intact patient specimens. Proc Natl Acad Sci USA 88: 9345-9349, 1991.

29 Metildi CA, Kaushal S, Luiken GA, Talamini MA, Hoffman RM and Bouvet $\mathrm{M}$ : Fluorescently-labeled chimeric anti-CEA antibody improves detection and resection of human colon cancer in a patient-derived orthotopic xenograft (PDOX) nude mouse model. J Surg Oncol 109: 451-458, 2014.

30 Hiroshima Y, Maawy A, Metildi CA, Zhang Y, Uehara F, Miwa S, Yano S, Sato S, Murakami T, Momiyama M, Chishima T, Tanaka K, Bouvet M, Endo I and Hoffman RM: Successful fluorescence-guided surgery on human colon cancer patientderived orthotopic xenograft mouse models using a fluorophoreconjugated anti-CEA antibody and a portable imaging system. J Laparoendosc Adv Surg Tech A 24: 241-247, 2014.

$31 \mathrm{Fu} \mathrm{X}$, Guadagni F and Hoffman RM: A metastatic nude-mouse model of human pancreatic cancer constructed orthotopically from histologically intact patient specimens. Proc Natl Acad Sci USA 89: 5645-5649, 1992.

32 Kaushal S, McElroy MK, Luiken GA, Talamini MA, Moossa AR, Hoffman RM and Bouvet M: Fluorophore-conjugated antiCEA antibody for the intraoperative imaging of pancreatic and colorectal cancer. J Gastrointest Surg 12: 1938-1950, 2008.

33 Suetsugu A, Katz M, Fleming J, Truty M, Thomas R, Saji S, Moriwaki $H$, Bouvet $M$ and Hoffman RM: Imageable fluorescent metastasis resulting in transgenic GFP mice orthotopically implanted with human-patient primary pancreatic cancer specimens. Anticancer Res 32: 1175-1180, 2012.

34 Suetsugu A, Katz M, Fleming J, Truty M, Thomas R, Saji S, Moriwaki $\mathrm{H}$, Bouvet $\mathrm{M}$ and Hoffman RM: Non-invasive fluorescent-protein imaging of orthotopic pancreatic-cancerpatient tumorgraft progression in nude mice. Anticancer Res 32: 3063-3068, 2012.

35 Hiroshima Y, Maawy A, Sato S, Murakami T, Uehara F, Miwa S, Yano S, Momiyama M, Chishima T, Tanaka K, Bouvet M, Endo I and Hoffman RM: Hand-held high-resolution fluorescence imaging system for fluorescence-guided surgery of patient and cell-line pancreatic tumors growing orthotopically in nude mice. J Surg Res 187: 510-517, 2014.

36 Hiroshima Y, Zhao M, Maawy A, Zhang Y, Katz MH, Fleming JB, Uehara F, Miwa S, Yano S, Momiyama M, Suetsugu A, Chishima T, Tanaka K, Bouvet M, Endo I and Hoffman RM: Efficacy of Salmonella typhimurium A1-R versus chemotherapy on a pancreatic cancer patient-derived orthotopic xenograft (PDOX). J Cell Biochem 115: 1254-1261, 2014.

37 Hiroshima Y, Maawy A, Zhang Y, Murakami T, Momiyama M, Mori R, Matsuyama R, Katz MH, Fleming JB, Chishima T, Tanaka K, Ichikawa Y, Endo I, Hoffman RM and Bouvet M: Metastatic recurrence in a pancreatic cancer patient derived orthotopic xenograft (PDOX) nude mouse model is inhibited by neoadjuvant chemotherapy in combination with fluorescenceguided surgery with an anti-CA 19-9-conjugated fluorophore. PLoS One 9: e114310, 2014.

38 Hiroshima Y, Zhang Y, Murakami T, Maawy AA, Miwa S, Yamamoto $M$, Yano $S$, Sato $S$, Momiyama $M$, Mori $R$, Matsuyama R, Chishima T, Tanaka K, Ichikawa Y, Bouvet M, Endo I, Zhao M and Hoffman RM: Efficacy of tumor-targeting Salmonella typhimurium A1-R in combination with antiangiogenesis therapy on a pancreatic cancer patient-derived orthotopic xenograph (PDOX) and cell line mouse models. Oncotarget 5: 12346-12357, 2014.

39 Hiroshima Y, Maawy AA, Katz MH, Fleming JB, Bouvet M, Endo I and Hoffman RM: Selective efficacy of zoledronic acid on metastasis in a patient-derived orthotopic xenograph (PDOX) nude-mouse model of human pancreatic cancer. J Surg Oncol 111: 311-315, 2015.

40 Hiroshima Y, Maawy A, Zhan Y, Murakami T, Momiyama M, Mori R, Matsuyama R, Chishima T, Tanaka K, Ichikawa Y, Endo I and Hoffman RM: Fluorescence-guided surgery, but not bright-light surgery, prevents local recurrence in a pancreatic cancer patientderived orthotopic xenograft (PDOX) model resistant to neoadjuvant chemotherapy (NAC). Pancreatology 15: 295-301, 2015.

41 Yano S, Hiroshima Y, Maawy A, Kishimoto H, Suetsugu A, Miwa S, Toneri M, Yamamoto M, Katz MH, Fleming JB, Urata Y, Tazawa H, Kagawa S, Bouvet M, Fujiwara T and Hoffman RM: Color-coding cancer and stromal cells with genetic reporters in a patient-derived orthotopic xenograft (PDOX) model of pancreatic cancer enhances fluorescence-guided surgery. Cancer Gene Therapy 22: 344-350, 2015.

$42 \mathrm{Fu}$ X, Le P and Hoffman RM: A metastatic-orthotopic transplant nude mouse model of human patient breast cancer. Anticancer Res 13: 901-904, 1993.

$43 \mathrm{Fu} \mathrm{X}$ and Hoffman RM: Human ovarian carcinoma metastatic models constructed in nude mice by orthotopic transplantation of histologically-intact patient specimens. Anticancer Res 13: 283-286, 1993.

44 Wang X, Fu X and Hoffman RM: A new patient-like metastatic model of human lung cancer constructed orthotopically with intact tissue via thoracotomy in immunodeficient mice. Int $\mathbf{J}$ Cancer 51: 992-995, 1992. 
45 Furukawa T, Kubota T, Watanabe M, Kitajima M, Fu X and Hoffman RM: Orthotopic transplantation of histologically intact clinical specimens of stomach cancer to nude mice: correlation of metastatic sites in mouse and individual patient donors. Int $\mathbf{J}$ Cancer 53: 608 612, 1993.

46 Astoul P, Wang X, Colt HG, Boutin C and Hoffman RM: A patient-like human malignant pleural mesothelioma nude-mouse model. Oncology Rep 3: 483-487, 1996.

47 Hiroshima Y, Zhao M, Zhang Y, Zhang N, Maawy A, Murakami T, Mii S, Uehara F, Yamamoto M, Miwa S, Yano S, Momiyama M, Mori R, Matsuyama R, Chishima T, Tanaka K, Ichikawa Y, Bouvet M, Endo I and Hoffman RM: Tumor-targeting Salmonella typhimurium A1-R arrests a chemo-resistant patient soft-tissue sarcoma in nude mice. PLoS ONE 10: e0134324, 2015.

48 Hiroshima Y, Zhang Y, Zhang N, Uehara F, Maawy A, Murakami T, Mii S, Yamamoto M, Miwa S, Yano S, Momiyama M, Mori R, Matsuyama R, Chishima T, Tanaka K, Ichikawa Y, Bouvet M, Endo I and Hoffman RM: Patientderived orthotopic xenograft (PDOX) nude mouse model of soft tissue sarcoma more closely mimics the patient behavior in contrast to the subcutaneous ectopic model. Anticancer Res 35: 697-701, 2015.

49 Murakami T, DeLong J, Eilber FC, Zhao M, Zhang Y, Zhang N, Singh A, Russell T, Deng S, Reynoso J, Quan C, Hiroshima Y, Matsuyama R, Chishima T, Tanaka K, Bouvet M, Chawla S, Endo I and Hoffman RM: Tumor targeting Salmonella typhimurium A1-R in combination with doxorubicin eradicate soft tissue sarcoma in a patient-derived orthotopic xenograft PDOX model. Oncotarget 7: 12783-12790, 2016.

50 Murakami T, Singh AS, Kiyuna T, Dry SM, Li Y, James AW, Igarashi K, Kawaguchi K, DeLong JC, Zhang Y, Hiroshima Y, Russell T, Eckardt MA, Yanagawa J, Federman N, Matsuyama R, Chishima T, Tanaka K, Bouvet M, Endo I, Eilber FC and Hoffman RM: Effective molecular targeting of CDK4/6 and IGF-1R in a rare FUS-ERG fusion CDKN2A-deletion doxorubicin-resistant Ewing's sarcoma in a patient-derived orthotopic xenograft (PDOX) nude-mouse model. Oncotarget 7: 47556-47564, 2016.

51 Kiyuna T, Murakami T, Tome Y, Kawaguchi K, Igarashi K, Zhang Y, Zhao M, Li Y, Bouvet M, Kanaya F, Singh A, Dry S, Eilber FC and Hoffman RM: High efficacy of tumor-targeting Salmonella typhimurium A1-R on a doxorubicin and dactolisibresistant follicular dendritic-cell sarcoma in a patient-derived orthotopic xenograft PDOX nude mouse model. Oncotarget 7 : 33046-3054, 2016.

52 Kiyuna T, Murakami T, Tome Y, Igarashi K, Kawaguchi K, Russell T, Eckardt MA, Crompton J, Singh A, Bernthal N, Bukata S, Federman N, Kanaya F, Eilber FC and Hoffman RM: Labeling the stroma of a patient-derived orthotopic xenograft (PDOX) mouse models of undifferentiated pleomorphic soft-tissue sarcoma with red fluorescent protein for rapid non-invasive drug screening. J Cell Biochem 118: 361-365, 2017.

53 Murakami T, Igarashi K, Kawaguchi K, Kiyuna T, Zhang Y, Zhao M, Hiroshima Y, Nelson SD, Dry SM, Li Y, Yanagawa J, Russell T, Federman N, Singh A, Elliott I, Matsuyama R, Chishima T, Tanaka K, Endo I, Eilber FC and Hoffman RM: Tumor-targeting Salmonella typhimurium A1-R regresses an osteosarcoma in a patient-derived xenograph model resistant to a molecular-targeting drug. Oncotarget 8: 8035-8042, 2017.
54 Igarashi K, Kawaguchi K, Kiyuna T, Murakami T, Miwa S, Nelson SD, Dry SM, Li Y, Singh A, Kimura H, Hayashi K, Yamamoto N, Tsuchiya H, Eilber FC and Hoffman RM: Patientderived orthotopic xenograft (PDOX) mouse model of adult rhabdomyosarcoma invades and recurs after resection in contrast to the subcutaneous ectopic model. Cell Cycle 16: 91-94, 2017.

55 Hoffman RM (ed.): Patient-derived mouse models of cancer. Molecular and translational medicine. Coleman, W.B., Tsongalis, G.J., (Series eds.) Springer Intl. Publishing AG, 2017. ISSN: 2197-7852.

56 Murakami T, Li S, Han Q, Tan Y, Kiyuna T, Igarashi K, Kawaguchi K, Hwang HK, Miyaki K, Singh AS, Nelson SD, Dry SM, Li Y, Hiroshima Y, Lwin T,M, DeLong JC, Chishima T, Tanaka K, Bouvet M, Endo I, Eilber FC and Hoffman RM: Recombinant methioninase effectively targets a Ewing's sarcoma in a patient-derived orthotopic xenograft (PDOX) nude-mouse model. Oncotarget 8: 35630-35638, 2017.

57 Kawaguchi K, Igarashi K, Murakami T, Kiyuna T, Nelson SD, Dry SM, Li Y, Russell TA, Singh AS, Chmielowski B, Unno M, Eilber FC and Hoffman RM: Combination of gemcitabine and docetaxel regresses both gastric leiomyosarcoma proliferation and invasion in an imageable patient-derived orthotopic xenograft (iPDOX) model. Cell Cycle 16: 1063-1069, 2017.

58 Igarashi K, Kawaguchi K, Murakami T, Kiyuna T, Miyake K, Nelson SD, Dry SM, Li Y, Yanagawa J, Russell TA, Singh A, Yamamoto N, Hayashi K, Kimura H, Miwa S, Tsuchiya H, Eilber FC and Hoffman RM: Intra-arterial administration of tumor-targeting Salmonella typhimurium A1-R regresses a cisplatin-resistant relapsed osteosarcoma in a patient-derived orthotopic xenograft (PDOX) mouse model. Cell Cycle 16: 1164-1170, 2017.

59 Murakami T, Kiyuna T, Kawaguchi K, Igarashi K, Singh A,S, Hiroshima Y, Zhang Y, Zhao M, Miyake K, Nelson SD, Dry SM, Li Y, DeLong JC, Lwin TM, Chishima T, Tanaka K, Bouvet M, Endo I, Eilber FC and Hoffman RM: The irony of highlyeffective bacterial therapy of a patient-derived orthotopic xenograft (PDOX) model of Ewing's sarcoma, which was blocked by Ewing himself 80 years ago. Cell Cycle 16: 10461052, 2017.

60 Igarashi K, Kawaguchi K, Murakami T, Kiyuna T, Miyake K, Singh A, Nelson SD, Dry SM, Li Y, Yamamoto N, Hayashi K, Kimura H, Miwa S, Tsuchiya H, Eilber FC and Hoffman RM: High efficacy of pazopanib on an undifferentiated spindle-cell sarcoma resistant to first-line therapy is identified with a patientderived orthotopic xenograft (PDOX) nude mouse model. J Cell Biochem 118: 2739-3743, 2017.

61 Igarashi K, Murakami T, Kawaguchi K, Kiyuna T, Miyake K, Zhang Y, Nelson SD, Dry SM, Li Y, Yanagawa J, Russell TA, Singh AS, Tsuchiya H, Elliott I, Eilber FC and Hoffman RM: A patient-derived orthotopic xenograft (PDOX) mouse model of an cisplatinum-resistant osteosarcoma lung metastasis that was sensitive to temozolomide and trabectedin: implications for precision oncology. Oncotarget 8: 62111-62119, 2017.

62 Igarashi K, Kawaguchi K, Kiyuna T, Murakami T, Miwa S, Nelson SD, Dry SM, Li Y, Singh A, Kimura H, Hayashi K, Yamamoto N, Tsuchiya H, Eilber FC and Hoffman RM: Temozolomide combined with irinotecan caused regression in an adult pleomorphic rhabdomyosarcoma patient-derived orthotopic xenograft (PDOX) nude-mouse model. Oncotarget 8: 75874$75880,2017$. 
63 Igarashi K, Kawaguchi K, Murakami T, Kiyuna T, Miyake K, Yamamoto N, Hayashi K, Kimura H, Nelson SD, Dry SM, Li Y, Singh A, Miwa S, Odani A, Eilber FC, Tsuchiya H and Hoffman RM: A novel anionic-phosphate-platinum complex effectively targets an undifferentiated pleomorphic sarcoma better than cisplatinum and doxorubicin in a patient-derived orthotopic xenograft (PDOX). Oncotarget 8: 63353-63359, 2017.

64 Miyake K, Murakami T, Kiyuna T, Igarashi K, Kawaguchi K, Miyake M, Li Y, Nelson SD, Dry SM, Bouvet M, Elliott IA, Russell TA, Singh AS, Eckardt MA, Hiroshima Y, Momiyama M, Matsuyama R, Chishima T, Endo I, Eilber FC and Hoffman RM: The combination of temozolomide-irinotecan regresses a doxorubicin-resistant patient-derived orthotopic xenograft (PDOX) nude-mouse model of recurrent Ewing's sarcoma with a FUS-ERG fusion and CDKN2A deletion: Direction for thirdline patient therapy. Oncotarget 8: 103129-103136, 2017.

65 Hiroshima Y, Zhang Y, Zhang M, Maawy A, Mii S, Yamamoto M, Uehara F, Miwa S, Yano S, Murakami T, Momiyama M, Chishima T, Tanaka K, Ichikawa Y, Bouvet M, Murata T, Endo I and Hoffman RM: Establishment of a patient-derived orthotopic xenograph (PDOX) model of HER-2-positive cervical cancer expressing the clinical metastatic pattern. PLOS ONE 10: e0117417, 2015.

66 Hiroshima Y, Maawy A, Zhang Y, Zhang N, Murakami T, Chishima T, Tanaka K, Ichikawa Y, Bouvet M, Endo I and Hoffman RM: Patient-derived mouse models of cancer need to be orthotopic in order to evaluate targeted anti-metastatic therapy. Oncotarget 7: 71696-1702, 2016.

67 Murakami T, Murata T, Kawaguchi K, Kiyuna T, Igarashi K, Hwang HK, Hiroshima Y, Hozumi C, Komatsu S, Kikuchi T, Lwin TM, Delong JC, Miyake K, Zhang Y, Tanaka K, Bouvet M, Endo I and Hoffman RM: Cervical cancer patient-derived orthotopic xenograft (PDOX) is sensitive to cisplatinum and resistant to nab-paclitaxel. Anticancer Res 37: 61-65, 2017.

68 Kawaguchi K, Murakami T, Chmielowski B, Igarashi K, Kiyuna T, Unno M, Nelson SD, Russell TA, Dry SM, Li Y, Eilber FC and Hoffman RM: Vemurafenib-resistant BRAF-V600E mutated melanoma is regressed by MEK targeting drug trametinib, but not cobimetinib in a patient-derived orthotopic xenograft (PDOX) mouse model. Oncotarget 7: 71737-71743, 2016.

69 Kawaguchi K, Igarashi K, Murakami T, Chmielowski B, Kiyuna T, Zhao M, Zhang Y, Singh A, Unno M, Nelson SD, Russell TA, Dry SM, Li Y, Eilber FC and Hoffman RM: Tumor-targeting Salmonella typhimurium A1-R combined with Temozolomide regresses malignant melanoma with a BRAF-V600 mutation in a patient-derived orthotopic xenograft (PDOX) model. Oncotarget 7: 85929-85936, 2016.

70 Yamamoto M, Zhao M, Hiroshima Y, Zhang Y, Shurell E, Eilber FC, Bouvet M, Noda M and Hoffman RM: Efficacy of tumortargeting Salmonella typhimurium A1-R on a melanoma patientderived orthotopic xenograft (PDOX) nude-mouse model. PLoS One 11: e0160882, 2016.

71 Kawaguchi K, Igarashi K, Murakami T, Zhao M, Zhang Y, Chmielowski B, Kiyuna T, Nelson SD, Russell TA, Dry SM, Li Y, Unno M, Eilber FC and Hoffman RM: Tumor-targeting Salmonella typhimurium A1-R sensitizes melanoma with a BRAF-V600E mutation to vemurafenib in a patient-derived orthotopic xenograft (PDOX) nude mouse model. J Cell Biochem 118: 2314-2319, 2017.
72 Kawaguchi K, Igarashi K, Chmielowski B, Murakami T, Kiyuna T, Zhao M, Zhang Y, Nelson SD, Russell TA, Dry SM, Singh AS, Li Y, Unno M, Eilber FC and Hoffman RM: Salmonella typhimurium A1-R targeting of a chemotherapy resistant BRAF$\mathrm{V} 600 \mathrm{E}$ melanoma in a patient-derived orthotopic xenograft (PDOX) model is enhanced in combination with either vemurafenib or temozlomide. Cell Cycle 16: 1288-1294, 2017.

73 Kawaguchi K, Igarashi K, Li S, Han Q, Tan Y, Kiyuna T, Miyake Y, Murakami T, Chmielowski B, Nelson SD, Russell TA, Dry SM, Li Y, Unno M, Eilber FC and Hoffman RM: Combination treatment with recombinant methioninase enables temozolomide to arrest a BRAF V600E melanoma growth in a patient-derived orthotopic xenograft. Oncotarget 8: 8551685525, 2017.

74 Kawaguchi K, Igarashi K, Li S, Han Q, Tan Y, Miyake K, Kiyuna T, Miyake M, Murakami T, Chmielowski S, Nelson SD, Russell TA, Dry SM, Li Y, Unno M, Eilber FC and Hoffman RM: Recombinant methioninase (rMETase) is an effective therapeutic for BRAF-V600E-negative as well as -positive melanoma in patient-derived orthotopic xenograft (PDOX) mouse models. Oncotarget 9: 915-923, 2018.

75 Nakamura M, Suetsugu A, Hasegawa K, Matsumoto T, Aoki H, Kunisada T, Shimizu M, Saji S, Moriwaki H and Hoffman RM: Genetic recombination between stromal and cancer cells results in highly malignant cells identified by color-coded imaging in a mouse lymphoma model. J Cell Biochem 118: 4216-4221, 2017.

76 Murakami T, Hiroshima Y, Miyake K, Hwang HK, Kiyuna T, DeLong JC, Lwin TM, Matsuyama R, Mori R, Kumamoto T, Chishima T, Tanaka K, Ichikawa Y, Bouvet M, Endo I and Hoffman RM: Color-coded intravital imaging demonstrates a transforming growth factor- $\beta$ (TGF- $\beta$ ) antagonist selectively targets stromal cells in a human pancreatic-cancer orthotopic mouse model. Cell Cycle 16: 1008-1014, 2017.

77 Allinen M, Beroukhim R, Cai L, Brennan C, Lahti-Domenici J, Huang H, Porter D, Hu M, Chin L, Richardson A, Schnitt S, Sellers WR and Polyak K: Molecular characterization of the tumor microenvironment in breast cancer. Cancer Cell 6: 17-32, 2004.

78 Suetsugu A, Jiang P, Yang M, Yamamoto N, Moriwaki H, Saji S and Hoffman RM: The use of living cancer cells expressing green fluorescent protein in the nucleus and red fluorescent protein in the cytoplasm for real-time confocal imaging of chromosome and cytoplasmic dynamics during mitosis. Anticancer Res 35: 2553-2558, 2015.
Received February 1, 2018

Revised February 28, 2018 Accepted March 6, 2018 